\title{
MASTER MASTER
}

ANNUAL PROGRESS REPORT COO-3221-55

(For the period September 77 - July 78)

Under Contract No E(11-1) -3221

\begin{abstract}
on
THE NATURE OF OXYGEN CONTAINING RADICALS IN RADIATION CHEMISTRY AND PHOTOCHEMISTRY OF AQUEOUS SOLUTIONS
\end{abstract}

Submitted by

PROFESSOR GIDON CZAPSKI

Department of Physical Chemistry

The Hebrew University, Jemsalem, Israel 


\section{DISCLAIMER}

This report was prepared as an account of work sponsored by an agency of the United States Government. Neither the United States Government nor any agency Thereof, nor any of their employees, makes any warranty, express or implied, or assumes any legal liability or responsibility for the accuracy, completeness, or usefulness of any information, apparatus, product, or process disclosed, or represents that its use would not infringe privately owned rights. Reference herein to any specific commercial product, process, or service by trade name, trademark, manufacturer, or otherwise does not necessarily constitute or imply its endorsement, recommendation, or favoring by the United States Government or any agency thereof. The views and opinions of authors expressed herein do not necessarily state or reflect those of the United States Government or any agency thereof. 


\section{DISCLAIMER}

Portions of this document may be illegible in electronic image products. Images are produced from the best available original document. 


\title{
ANNUAL PROGRESS , REPORT COO-3221-55 \\ (For the period September 77 - July 78) \\ Under Contract No $E(11-1)-3221$
}

on

THE NATURE OF OXYGEN CONTAINING "RADICALS IN

RADIATION CHEMISTRY AND PHOTOCHEMISTRY OF AQUEOUS SOLUTIONS

\author{
Submitted by
}

PROFESSOR GIDON" CZAPSKI

Department of Physical Chemistry

The Hebrew University, Jerusalem, Israel

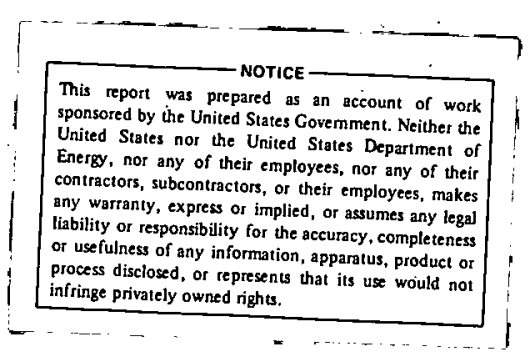




\section{ANNUAL PROGRESS REPORT}

(December 1977 - July 1978)

ON

\section{THE NATURE OF OXYGEN CONTAINING RADICALS IN}

\section{RADIATION CHEMISTRY AND PHOTOCHEMISTRY OF AQUEOUS SOLUTIONS}

\section{INSTITUTIONS}

This research will be carried out at the Department of Physical Chemistry and in the Linear Accelerator Department, The Hebrew University of Jerusalem, Israel.

\section{PROJECT ABSTRACI}

The proposed research is a continuation of the work donducted under this contract and is outlined. During this year, the main emphasis will be given to study further the properties of $\mathrm{HO}_{2}$ and $\mathrm{O}_{2}^{-}$and $\mathrm{OH}^{\circ}$, mainly in their role in biological systems.

We will continue to study and elucidate how $\mathrm{O}_{2}^{-}$reacts in biological systems. The toxidity of $\mathrm{O}_{2}^{-}$is quite well established but the mechanism is still obscure. The Haber Weiss reaction most probably can not account for the toxidity of $0_{2}^{-}$nor for the formation of singlet oxygen, nor of $\mathrm{OH}^{\circ}$.

We will study if reduction of $\mathrm{Fe}^{3+}$ complexes by $\mathrm{O}_{2}^{-}$in biological systems does catalyze the Haber Weiss reaction and if $\mathrm{OH}^{\circ}$ is formed in this mechanism. The role of oxygen, radiosensitizers in radiation damage of bactriophages and cells will be further studied.

We will try to elucidate the formation. and role of $\mathrm{OH}^{\circ}, \mathrm{O}_{2}^{-}$and $\mathrm{O}_{2}$ in these systems as well as the relative contribution of endogenous and exogenous damage, and the role of direct and indirect radiation damage to cells. 
We intend also to study if SOD (super oxide dismutase) does react only with $\mathrm{O}_{2}^{-}$or also with biological peroxides $\left(\mathrm{RO}_{2}^{\circ}\right)$ and Hydroperoxides $\left(\mathrm{RO}_{2} \mathrm{H}\right)$.

Further studies of $\mathrm{O}_{2}^{-}$and $\mathrm{O}_{2}$ with various cytochromes, and Hemoglobins is planned。 


\section{RESEARCH PROPOSED ORIGINALLY AND SUMMARY OF ACHIEVEMENTS}

\section{DURING THE PREVIOUS YEARS}

The research project proposed originally was to investigate the physical and chemical properties of Ozonide and Hydro-peroxy radical mainly in aqueous solutions.

We will summarize the results of the problems suggested and studied during the previous years by us.

\section{a. OZONIDE ION}

We established the spectrum of this species as well as the decay and formation kinetics of the ozonide. The reaction mechanism and kinetics $\mathrm{O}_{3}^{-}$with other solutes were measured and shown to follow by the dissociation of $0_{3}^{-}$.

\section{b. HYDRO-PEROXY RADICAL}

We determined the properties of this species. It was shown that it exists as $\mathrm{HO}_{2}$ and $\mathrm{O}_{2}^{-}$with $\mathrm{pK} \sim 4.85$. The additional form of the radical $\mathrm{H}_{2} \mathrm{O}_{2}^{+}$proposed, seems to be ruled out in solutions down to $\mathrm{pH}=0$. The decay scheme of the radical was well established, including the separate rate constants for the reactions $\mathrm{HO}_{2}+\mathrm{HO}_{2}, \mathrm{HO}_{2}+\mathrm{O}_{2}^{-}$and $\mathrm{O}_{2}^{-}+\mathrm{O}_{2}^{-}$. The optical spectrum of $\mathrm{HO}_{2}$ and $\mathrm{O}_{2}^{-}$were determined.

\section{c. COMPLEXES OF $\mathrm{HO}_{2}$ WITH CATIONS}

It was shown that $\mathrm{HO}_{2}$ forms complexes with many cations yielding $\mathrm{MHO}_{2}$. These species are much more stable than the free radical, and they have typical ESR signals. It was found that these complexes undergo readily exchange reactions of the following type.

$$
\mathrm{MHO}_{2}+\mathrm{M}^{\prime} \rightleftharpoons \mathrm{M}^{\prime} \mathrm{HO}_{2}+\mathrm{M}
$$

\section{d. ESR DETECTION WITH IN SITU PHOTOLYSIS USING MODULATED LIGHT}

In this method radicals were generated in situ in an ESR cavity by photolysis. The light source was modulated and square pulses with pulse length of $10^{-5} \mathrm{sec}$ were obtained with frequencies of $5 \mathrm{H}_{z}-4 \mathrm{KH}_{z}$. By this method, radicals reach 
concentrations at the end of pulses which were as low as $10^{-9} \mathrm{M}$ and decay till the next pulse. Using a wave from educator, one can average the ESR signal over many pulses and good signal/noise is obtained although of the very low concentration obtained by this method. In order to prevent depletion, the solutions being changed in the cavity by a slow flow system.

This method was used to follow the decay kinetics of several complexes, such as $\mathrm{Th}-\mathrm{HO}_{2}$.

The method has the advantage to follow reactions of $\mathrm{Th}-\mathrm{HO}_{2}$ at $1 \mathrm{ow}$ concentrations, where 2nd order recombination is neglible while with usual techniques one can not prevent the 2 nd order decay, as in these methods much higher concentrations of $\mathrm{Th}-\mathrm{HO}_{2}$ are formed.

\section{e. EQUILIBRIA CONSTANTS OF $\mathrm{MHO}_{2}$ COMPLEXES}

We further studied the equilibria of $\mathrm{MHO}_{2}$ complexes

$$
\mathrm{M}+\mathrm{HO}_{2} \rightleftharpoons \mathrm{MHO}_{2}
$$

We determinated a few more values of such equilibrium constants with various methods. We also extended the study of the exchange reaction.

$$
\mathrm{M}+\mathrm{M}^{\prime} \mathrm{HO}_{2} \rightleftharpoons \mathrm{MHO}_{2}+\mathrm{M}
$$

and varified and determined some new equilibria constants for this kind of exchange.

\section{f. RATE AND MECHANISM OF COMPLEX FORMATION AND EXCHANGE REACTIONS}

We determined the rate of formation of $\mathrm{MHO}_{2}$ through reaction (1) and the exchange rates (reaction 2) for various cations, such as $\mathrm{Th}^{4+}$, $\mathrm{U}^{6+}$, etc. The result indicates that these rates are very fast, and the exchange mechanism (2) may go on either directly (2) or more probably through dissociation of $\mathrm{MHO}_{2}(1)$.

g. COMPLEXES OF $\mathrm{Fe}^{3+}$ AND $\mathrm{Cu}^{2+}$ WITH $\mathrm{HO}_{2}$

We continued to establish the existence of complexes of $\mathrm{Cu}^{2+}$ and $\mathrm{Fe}^{3+}$ with $\mathrm{HO}_{2}$. Such complexes could be of interest, in view of the biological role of $\mathrm{Fe}^{3+}$ and $\mathrm{Cu}^{2+}$ compcunds in reactions with $\mathrm{HO}_{2}$ in such systems. 
Concerning the existence of $\mathrm{CuHO}_{2}^{2+}$ we got good kinetic evidence, although this comlpex is short lived and therefore its concentration was too low to record its optical or ESR spectra.

h. OPTICAL SPECTRA OF $\quad \mathrm{HHO}_{2}$

While the existence of $\mathrm{MHO}_{2}$ complexes were established and its ESR spectra recorded previously, their optical spectra were not known. Using the pulse radiolysis we were able to observe the optical spectra of $\mathrm{ThHO}_{2}^{2+} \mathrm{UHO}_{2}^{6+}$ and study these species by absorption spectroscopy.

i. REACTIONS OF $\mathrm{H}_{2} \mathrm{O}_{2}$ WITH $\mathrm{Ce}^{4+}, \mathrm{Ti}^{3+}, \mathrm{Fe}^{2+}$ and $\mathrm{Cr}^{2+}$

The radical $\mathrm{OH}$ formed in photolysis of $\mathrm{H}_{2} \mathrm{O}_{2}$ or in radiolysis of aqueous solution was well established for years. It was believed that the same radical may be formed by reacting $\mathrm{H}_{2} \mathrm{O}_{2}$ with $\mathrm{Ti}^{3+}, \mathrm{Fe}^{2+}$, or $\mathrm{Cr}^{2+}$. Nevertheless, many experimental results indicated, that $\mathrm{OH}$ is not formed in all these cases and we explained the reasons that earlier studies seemed to contradict this finding.

We were also able to generate $\mathrm{HO}_{2}$ from $\mathrm{Ce}^{4+}$. and $\mathrm{H}_{2} \mathrm{O}_{2}$ and from excess of $\mathrm{H}_{2} \mathrm{O}_{2}$ with either $\mathrm{Ti}^{3+}, \mathrm{Fe}^{2+}$ or $\mathrm{Cr}^{2+}$. The importance of these studies is in the ability to generate $\mathrm{HO}_{2}$ and $\mathrm{OH}$ chemically.

$j: \quad$ USE OF FLOW METHODS FOR KINECTIC AND MECHANISTIC STUDIES

The use of mixtures of $\mathrm{Ti}^{3+}$ and $\mathrm{H}_{2} \mathrm{O}_{2}$ in flow systems was widely employed in studies of radicals by ESR method. The method is based on flowing $\mathrm{H}_{2} \mathrm{O}_{2}$ with some solute $\mathrm{RH}$ and mixing it with $\mathrm{Ti}^{3+}$ in front of and ESR cavity.

By this method one obtains high concentrations of radicals in the ESR cavity, and the method is capable to produce many different radicals.

The wide use of the method is due to its advantage in being cheap, yielding high concentrations of various radicals and giving good ESR signals.

As long as the method was used only to characterize the ESR signals of radicals the method proved to be very valuable. Nevertheless, the method was later used to study the kinetics of the radicals formation, decay and other reactions, and also to study reaction mechanisms. In kinetic and mechanistic 
studies many results seemed to be in conflict with other studies. We were able to show the reason for these contraversies, as we proved there is an error in the assumptions in using the method for kinetic studies. As in this method, generaaly the radicals observed in the cavity are formed inside the cavity, and are not radicals which are formed out of the cavity (in the mixer), therefore the method is useless for kinetic studies, and may lead aslo to wrong reaction mechanisms.

For this reason, it was shown that double mixing previously used in these studies is completely meaningless.

\section{k. THE CATALYTIC MECHANISM OF MANGANESE-CONTAINING DISMUTASE}

The pulse radiolysis method was used to investigate the enzymatic mechanism of $\mathrm{HO}_{2}$ dismutation. The enzyme studied was the Manganese-containing dismutase of Escheridria coli. The results were interpreted in terms of four oxidation and reduction reactions as follows:
1) $\mathrm{E}+\mathrm{O}_{2}^{-} \longrightarrow \mathrm{E}^{-}+\mathrm{O}_{2}$
or $\mathrm{E}+\mathrm{O}_{2}^{-} \stackrel{2 \mathrm{H}^{+}}{\longrightarrow} \mathrm{E}^{+}+\mathrm{H}_{2} \mathrm{O}_{2}$
$\mathrm{k}=1.3 \pm 0.15 \times 10^{9} \mathrm{M}^{-1} \mathrm{sec}^{-1}$
2) $\mathrm{E}^{-}+\mathrm{O}_{2}^{-} \stackrel{2 \mathrm{H}^{+}}{\longrightarrow} \mathrm{E}+\mathrm{H}_{2} \mathrm{O}_{2}$
or $\mathrm{E}^{+}+\mathrm{O}_{2}^{-} \longrightarrow \mathrm{E}+\mathrm{O}_{2}$
$k=1.6 \pm 0.6 \times 10^{9} \mathrm{M}^{-1} \mathrm{sec}^{-1}$
3) $\mathrm{E}^{-}+\mathrm{O}_{2}^{-} \longrightarrow \mathrm{E}^{2-}+\mathrm{O}_{2}$
$k \sim 2 \times 10^{8} \mathrm{M}^{-1} \sec ^{-1}$
or $\quad \mathrm{E}+\mathrm{O}_{2}^{-} \longrightarrow \mathrm{E}^{-}+\mathrm{O}_{2}$
4) $\mathrm{E}^{2}+\mathrm{O}_{2}^{-} \stackrel{2 \mathrm{H}^{+}}{\longrightarrow} \mathrm{E}^{-}+\mathrm{H}_{2} \mathrm{O}_{2}$
or $\mathrm{E}^{-}+\mathrm{O}_{2}^{-} \stackrel{2 \mathrm{H}^{+}}{\longrightarrow} \mathrm{E}+\mathrm{H}_{2} \mathrm{O}_{2}$
$k \sim 10^{7} \mathrm{M}^{-1} \sec ^{-1}$

$\mathrm{E}^{+}, \mathrm{E}, \mathrm{E}^{-}$and $\mathrm{E}^{2-}$ may represent forms of the enzyme in which $\mathrm{Mn}$ is possibly present in valence I, II, III, IV. It was shown that after about $30 \mathrm{sec}$ of the end of the catalytic process the enzyme activity is completely regenerated. 


\section{DETERMINATION OF REDOX POTENTIALS OF FREE RADICALS}

Most of our effort during 1974-1975 wad dedicated to the problem of determination of redox potentials of free radicals, using the pulse radiolysis technique. This study was also extended during the past years. The basic idea of this approach is an obvious one, namely to find an electron ecceptor A or a donor $D$ which react with the free radical as follows:

$$
\begin{aligned}
& \mathrm{R}+\mathrm{A} \cdot \rightleftharpoons \mathrm{R}^{+}+\mathrm{A}^{-} \\
& \text {or } \mathrm{R}+\mathrm{A} \rightleftharpoons \mathrm{R}^{-}+\mathrm{D}^{+}
\end{aligned}
$$

These electron transfer reactions can and were widely studied. If for a given radcial $R$ an appropriate acceptor or donor is found, so that one of these reactions reaches equilibrium, than if the equilibrium constant can be measured, one may obtain the radicals' redox potential. There are several assumptions and conditions which have to be fulfilled in order to use this methods for the determination of redox potentials:

1) The reaction has to be reversible and equilibrium has to be achieved.

2) The equilibrium is not too far neither to the left nore to the right, otherwise the equilibrium constant will not be measurable.

3) The redox potential of the respective acceptor or donor is known. It happens that it is not easy to find a system where all these conditions hold. Therefore in some earlier work of Willson and Patel $\mathrm{K}_{\mathrm{e}_{\mathrm{q}}}$ for the electron transfer was measured (conditions 1 and 2 were fulfilled), but the redox potential of $R$ could not have been calculated as it was not known for the acceptor. The method is briefly as follows: The knowledge of $\mathrm{Ke}_{\mathrm{f}}$ for the electron transfer reaction enables to calculate $\Delta G^{\circ}$ and $\Delta E^{\circ} . \Delta E^{\circ}$ is given as the difference of the redox potentials of the radical and the acceptor. Hayon and Coworkers published recently many studies, using this method, in which they claimed to have determined redox potentials of dozens of radicals. We have shown that their method was used wrongly for two reasons and hence their results are meaningless:

a) In all of their studies, except in the $\mathrm{O}_{2}^{-}$case, equilibrium was never achieved and the reaction was not reversible. 
b) In a11 their calculations they used wrong values of the redox potential of the acceptors and donors.

Recently they withdrew most of their conclusions in view of our criticism.

The difficulty using this method lies in the fact that most "suitable" acceptors are organic molecules. For organic molecules, oxidation reduction reactions are envolving a two electron transfer, for which $\mathrm{E}^{0}$ is mostly known. Nevertheless in the electron transfer reaction with the radical the one electron transfer step is observed and followed.

For the one electron transfer very seldom the $\mathrm{E}^{\mathrm{o}}$ value is known as it envolves itself a free radical which is unstable.

After we analyzed the limitations of the method we used it to determine several redox potentials under conditions where the method is justified.

m. THE REDOX POTENTIAL OF THE $\mathrm{O}_{2} / \mathrm{O}_{2}^{-}$AND $\mathrm{O}_{2}^{-} / \mathrm{H}_{2} \mathrm{O}_{2}$ COUPLES

The redox potential of $\mathrm{O}_{2}^{-}$was determined by measuring the equilibria between $\mathrm{O}_{2}^{-}$and several semiquibones.

$$
\mathrm{Q}+\mathrm{Q}_{2}^{-} \rightleftharpoons \mathrm{Q}^{-}+\mathrm{O}_{2}
$$

The redox potential of $\mathrm{Q}^{-} \mathrm{Q}^{-}$was not known, but we could calculate it from the values of $\mathrm{E}^{\circ}\left(\mathrm{Q} / \mathrm{Q}^{--}\right)$and from the equilibrium constant of the reaction $2 Q^{-} \rightleftarrows Q \mp Q^{--}$, both of these data were available in the literature. Once we had the redox potential of $\mathrm{O}_{2}^{-} / \mathrm{O}_{2}$ and the literature value of $\mathrm{O}_{2} / \mathrm{H}_{2} \mathrm{O}_{2}$, we calculated also the redox potential of $0_{2}^{-} / \mathrm{H}_{2} \mathrm{O}_{2}$. Our results are given below:

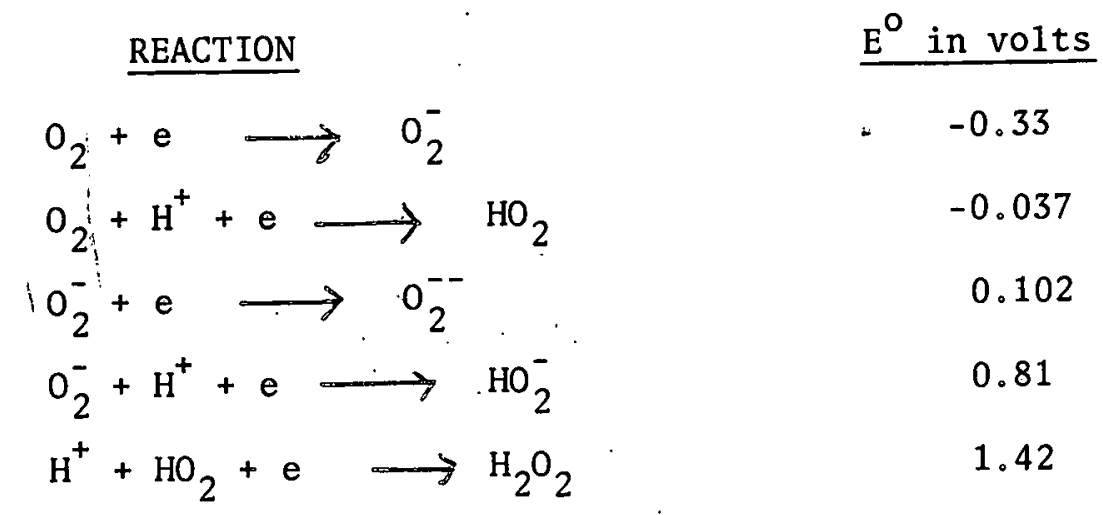


These values differ substantially from earlier estimates. These potentials are very importent as $\mathrm{O}_{2}^{-}$is an important intermediate in many biological processes, such as in the reduction of molecular oxygen. These data were obtained already in 1974-75 and were reported last year. Due to the importance of the value of $\mathrm{E}^{\mathrm{O}}\left(\mathrm{O}_{2} / \mathrm{O}_{2}^{-}\right)$we extended the study over additional systems. A11. our latest results confirm the above mentioned value.

\section{n. DETERMINATION OF REDOX POTENTIALS OF OTHER RADICALS}

We have determined with the above mentioned method, redox potentials of some additional free radicals, such as several semiquinones. Dr.D.Meisel, now at the Mellon Institute, continued this work there and measured redox potentials of several nitro compounds.

\section{o. THE REACTION OF PEROXY RADICALS FORMED FROM ISOPROPANOL}

Isopropanol radical was generated by the pulse radiolysis technique by abstraction of a $\mathrm{H}$ atom from isopropanol by an $\mathrm{OH}$ : The reaction of $\mathrm{O}_{2}$ with the radical $R$ was studied.

$$
\begin{aligned}
& \mathrm{RH}_{2}+\mathrm{OH} \longrightarrow \mathrm{H}_{2} \mathrm{O}+\mathrm{RH}^{\circ} . \\
& \mathrm{RH}^{\circ}+\mathrm{O}_{2} \longrightarrow \mathrm{RHO}_{2} \text { or } \mathrm{R}+\mathrm{HO}_{2}
\end{aligned}
$$

It was established that $\left(\mathrm{CH}_{3}\right)_{2}-\mathrm{C}(\mathrm{OH})-\mathrm{O}_{2}$ is formed. Its spectrum and decay kinetics were studied. By catalysis of $\mathrm{HPO}_{4}^{2+}$, the radical decomposes to yield $\mathrm{O}_{2}$ and acetone. There were some doubts previously if in reaction (b) $\mathrm{HO}_{2}$ is directly formed, this study indicates the $\mathrm{RHO}_{2}$ is formed, but does yield under given condition $0_{2}^{-}$quite fast.

\section{p. THE PEROXY RADICALS OF ACETATE}

We extended the studies on $\mathrm{MeOH}$ and $\mathrm{PrOH}$ to glycine. It was found also with this substrate that the glycine radical reacts with $\mathrm{O}_{2}$ to yield the glycine peroxy radical. This radical also decomposes rapidly $\left(k=1.25 \times 10^{5} s^{-1}\right)$ to yield the $\mathrm{O}_{2}^{-}$radical. 
q. THE FORMATION OF CrO $2+$ IN THE REACTION $\mathrm{Cr}^{2+}+\mathrm{O}_{2}$

The reduction rate of $\mathrm{Cr}^{3+}$ by $\mathrm{e}_{\mathrm{aq}}$ was determined, $\mathrm{k}=1.7 \times 10^{10} \mathrm{M}^{-1} \mathrm{sec}^{-1}$. The $\mathrm{Cr}^{2+}$ thus produced by pulse radiolysis was reacted with $\mathrm{O}_{2}$. The same reaction was also studied with the fast flow technique, by mixing $\mathrm{Cr}^{2+}$ with and oxygenated acid solution. The rate of the reaction

$$
\mathrm{O}_{2}+\mathrm{Cr}^{2+} \mathrm{CrO}_{2}^{2+} \text { is } \mathrm{k}=1.6 \times 10^{8} \mathrm{M}^{-1} \mathrm{sec}^{-1}
$$

The interesting feature of this simple reaction is the formation of a complex $\mathrm{CrO}_{2}^{2+}$ whose spectrum and decay kinetics were studied. In contrast to $\mathrm{Zn}^{2+}$ and $\mathrm{Co}^{2+}$, which in their reactions with $\mathrm{O}_{2}$ proceed via electron transfer, this reaction of $\mathrm{Cr}^{2+}$ is similar to that of Hemoglobin by a complex rather than electron transfer.

\section{: \\ $r$ OXIDATION OF HEME BY $\mathrm{O}_{2}, \mathrm{O}_{2}^{-}$FERRICYANIDE}

In this study we produced heme in the presence of the oxidizing species $\mathrm{O}_{2}, \mathrm{O}_{2}^{-}$and $\mathrm{Fe}(\mathrm{CN})_{6}^{3-}$. We followed the reactions of the heme with these species. In alkaline solutions, the heme reduced $0_{2}$, probably by an outersphere mechanism and did not react appreciably with $0_{2}^{-}$. In neutral solution the heme reacted both with $\mathrm{O}_{2}$ and $\mathrm{O}_{2}^{-}$. At both $\mathrm{pH}$ values we could not observe any complex formation. The rate of the reduction of ferricyanide by heme was similar, in neutral and alkaline solutions.

s. THE REACTION OF $\mathrm{Mn}^{2+}$ with $0_{2}^{-}, \mathrm{OH}, \mathrm{e}_{\mathrm{aq}}^{-}$and $\mathrm{CO}_{2}^{-}$

The reaction rates of $\mathrm{Mn}^{2+}$ with reducing agents such as $\mathrm{CO}_{2}^{-}$and $\mathrm{e}_{\text {aq }}^{-}$, were measured and were found to be quite slow $\left(2 \times 10^{5}\right.$ and $10^{7} \mathrm{M}^{-1} \mathrm{~s}^{-1}$ respectively).

The oxidations of $\mathrm{Mn}^{2+}$ with $\mathrm{OH}^{\circ}$ was found to be $\mathrm{k}=3.4 \times 10^{7} \mathrm{M}^{-1} \mathrm{~s}^{-1}$. The reaction of $\mathrm{O}_{2}^{-}$with $\mathrm{Mn}^{2+}$ is of interest as $\mathrm{Mn}$ constitutes an active site in superoxide dismutase. The reaction of $\mathrm{O}_{2}^{-}$with $\mathrm{Mn}^{2+}$ has a rate constant of $10^{8} \mathrm{M}^{-1} \mathrm{~s}^{-1}$ and was found to be reversibly $\mathrm{K}=1.5 \times 10^{4} \mathrm{M}^{-1}$. The reaction product $\therefore$ is either $\mathrm{Mn}^{3+}$ or $\mathrm{MnO}_{2}^{+}$。

The surprising fact is that $\mathrm{Mn}^{2+}$ does not catalyze the dismutation of $0_{2}^{-}$. 


\section{PUBLICATIONS ASSOCIATED WITH THIS CONTRACT}

\section{DURING THE YEARS $67-78$}

The publications associated with this project include 54 technical progress reports of which six were submitted during the last year. In addition, out of this research 41 papers appeared in the various journals of which 3 came into the journals in the last year. Further 4 papers were submitted, 3 of them are in print.

\section{BIBLIOGRAPHY OF PUBLICAIIONS ASSOCIATED WITH THIS CONTRACT UP TO DATE}

1. Progress reports No. 1 - No. 54.

2. Czapski, G。 and Halperin, $B_{0}$, on the $U_{0} V_{0}$ spectrum of $\mathrm{O}_{2}^{-}$in solutions. Israel $J_{0}$ of Chem. $5,185-191$ (1967)。

3. Behar, D. and Czapski, G. Flash photolysis of $\mathrm{H}_{2} \mathrm{O}_{2} \mathrm{I}$ : The reaction of $\mathrm{O}_{3}^{-}$, with $\mathrm{H}_{2} \mathrm{O}_{2}$, Israel $J_{0}$ of Chem。, 6, 43-51 (1968).

4. Czapski, G。 Oxygen containing intermediates of Photochemistry and Radiation Chemistry, Radiation Chemistry of Aqueous Systems, 211-227. The Weizmann Science Press, Jerusalem, 1968.

5. Czapski, G。 and Rabani, I. The use of O.D. paper for an easy evaluation of osciloscope traces. Israel $J_{0}$ of Chem., $\underline{7}, 167-169$ (1969)。

6. Czapski, G。, Samuni, A. and Yelin, R., The decay of Ozone in alkaline solution, Israel $J_{0}$ of Chem。 6 , 969-971 (1969).

7. Amichai, 0., Czapski, Go and Treinin, A., Flash photolysis of the oxybromine Anions, Israel $J_{0}$ of Chem., $\underline{7}, 351-359$ (1969).

8. Czapski, G. and Samuni, A., The kinetics of complexes and free $\mathrm{HO}_{2}$ radical in the reaction of $\mathrm{Ce}^{4+}$ and $\mathrm{H}_{2} \mathrm{O}_{2}$, Israel $J_{0}$ of Chem., 361-373 (1969).

9. Czapski, G。, Levanon, $\mathrm{H}_{\text {。 }}$ and Samuni, A., ESR studies of uncomplexed and complexed $\mathrm{HO}$ radical formed in the reaction of $\mathrm{H}_{2} \mathrm{O}_{2}$ with $\mathrm{Ce}^{+4}, \mathrm{Fe}^{+2}$ and $\mathrm{Ti}+3$ ions. Israel $J_{\text {: }}$ of Chem., $\underline{7}, 375-386$ (1969).

10. Behar, Do and Czapski, G., Ozonide and Hydrogoperoxy radicals in $f 1$ ash photolysis of $\mathrm{H}_{2} \mathrm{O}_{2}$, Israel $J$ of Chem., $\underline{8}$, 699-708 (1970).

11. Behar, D., Czapski, G. and Duchovni, I., $\mathrm{CO}_{3}^{-}$radical in flash photolysis and Pulse radiolysis of Aqueous carbonate. $J_{0}$ Phys. Chem., 74 2206-2210 (1970). 
12. Czapski, G。 and Samuni, A., ESR study of a complex formation between $\mathrm{HO}_{2}$ radical and Peroxy-Vanadiumm (V) ion. Israel J. of Chem., 8 , 563-573 (1970)。

13. Czapski, G。 and Samuni, A。, Oxidation of $\mathrm{Ce}^{+3}$ by $\mathrm{HO}_{2}$ radical and $\mathrm{Ce}^{+3}-$ $\mathrm{HO}_{2}$ complex formation. Israel $J$ of Chem., 8 , 551-562 (1970).

14. Behar, D。, Czapski, G。, Rabani, I。, Dorfman, L。M. and Schwarz, H.A., The Acid dissociation constant and decay kinetics of the Perhydroxyl Radical. Jo Phys。Chem., 74, 3209-3213 (1970).

15. Czapski, G。, Radiation Chemistry of oxygenated Aqueous Solutions, Ann. Rev。 Phys. Chem., pp. 171-208 (1971)。

16. Czapski, G. and Samuni, A., Complexes of $\mathrm{HO}_{2}$ radical with transition metal ions. J. Phys. Chem。, 74, 4592-4594 (1970)。

17. Czapski, G。 and Meise1, D., The role of the reaction of $e_{a q}^{-}$with $\mathrm{Fe}^{+3}$ in the radiation chemistry of acid aqueous solutions. Inter. J. Rad. Phys. Chem., 3, 11-16 (1971)。

18. Czapski, G. Samuni, A. and Meise1, D. On the reaction of organic radicals formed by some "Fenton-like" reagents. J. Phys. Chem., 3271-3280 (1971)。

19. Czapski, G。 On ESR Studies of short living radicals generated by fast flow methods in Aqueous Solutions. $J$. Phys. Chem., 75, 2957-2967 (1971).

20. Samuni, A。, Meise1, D。 and Czapski, G. The Kinetics of Oxidtation of $\mathrm{Cr}$ (II), Ti(III) and $\mathrm{V}(\mathrm{IV})$ by $\mathrm{H}_{2} \mathrm{O}_{2}$ and $\mathrm{OH}$. J. Chem。 Soc., (Dalton Trans), 1273-1277 (1972)。

21. Samuni, A. and Czapski, G. The reaction of $\mathrm{Ce}$ (IV) perchlorate with $\mathrm{H}_{2} \mathrm{O}_{2}$ J.Chem.Soc., (Dalton Trans), 487-488 (1973):

22. Czapski, G。 The Hydroperoxy radical in Aqueous Solutions. Israel J. Chem. 10, $987-997$ (1972)。

23. Meise1, D。, Czapski, G. and Samuni, A. Hydroperoxy radical reactions $\mathrm{I}$ :ESR study of the complexation of $\mathrm{HO}_{2}$ with some metal ions. J. Am. Chem. Soc., 95, 4148-4153 (1973).

24. Meise1, D., Czapski, G. and Samuni, A. On the use of ESR flow technique in the study of short living radicals. $J$. Chem.Soc., (Perk. Section), $17,02-1708$ (1973)。

25. Czapski, G。, Meisel, D. and Levanon, $H_{0}$ Hydroperoxyl radical reactions II - Cupric ions in modulated photolysis - EPR experiments. J. Phys. Chem. $\underline{78}, 779-782(1974)$. 
26. Meise1 D., Ilan, Y.A. and Czapski, G. Hydroperoxyl reactions III - pulse Radiolytic study of reaction of $\mathrm{HO}_{2}$ with some metal ions. Phys. Chem., 78, 2330-2332 (1974)。

27. Ilan, Y.A., Meise1, D., and Czapski, G. The redox potential for the $(1974)^{2}$ system in aqueous media. Israel $j_{0}$ of Chem., 12, 891-895

28. Pick, M。, Rabani, J., Yost, F。 and Fridovich, I. The catalytic mechanism of the manganese-containing superoxide dismutase of Escherichia coli studies by pulse radiolysis. J. Amer. Chem. Soc., 96, 7329-7333 (1974).

29. Meise1, D. and Czapski, G. One electron transfer equilibria and Redox Potentials of radicals studied by pulse radiolysis. J. Phys. Chem., 79, 1503-1509 (1975)。

30. Ilan, A.Y., Czapski, G。 and Ardon, M. The formation of $\mathrm{CrO}_{2}^{2+}$ in the Reaction of $\mathrm{Cr}^{2+}+\mathrm{O}_{2}$ in Aqueous acid solutions. Israel $\mathrm{J}$. of Chem., $13,15-21$ (1975)。

31. Ilan, A.Y.Czapski, G. and Meisel, D. The Determination of the One electron transfer redox potentioals of Free Radicals - Proc. Israel Chemical Society $43 \dot{r} d$ meeting 7 (1975)。

32. Ilan, A.Y., Czapski, G. and Meise1, D. The one electron transfer redox potential of free radicals. B.B.A., 430, 209-224 (1976).

33. Ilan, A. Y., Rabani, J. On some fundamental reactions in radiation chemistry: nanosecond pulse radiolysis. Int. J. Radiat Phys. Chem., 8, 609-611 (1976):

34. Klug-Roth, D。, Rabani, J. Pulse Radiolytic Studies on Reactions of Aqueous Superoxide. Radicals with Copper(II) Complexes. J. Phys. Chem., 80, 588-591 (1976).

35. (Dinur) Abramovitch, S., and Rabani, J. Pulse Rad'blytic Investigation of Peroxy Radicals in Aqueous Solutions of Acetate and Glycine. $J$. Phys. Chem., 80, 1562-1565 (1976).

36. Ilan, Y。A。, Rabani, J., and Henglein, A。 Pulse Radiolytic Investigations of Peroxy Radicals Produced from 2-Propanol and Methanol. J. Phys. Chem., $80,1558-1562(1976)$.

37. Ilan, Y.A., Czapski, G., and Meise1, D。 The One-Electron Transfer Redox Potentials of Free Radicals. The Oxygen/Superoxide System. B.B.A., 430, 209-224 (1976)。

38. Ilan, Y. $A_{\circ}$, Rabani, J。 and Czapski, G。 One electron reduction of Memyoglobin and Methemoglobin and the reaction of the reduced molecule with Oxygen。Ibid. 446, 277-286 (1976)。 
39. Pick-Kaplan, M., and Rabani, J. Pulse kadiolytic studies of Aqueous $\mathrm{Mn}\left(\mathrm{C}_{4}\right)_{2}$ Solutions. J. Phys. Chem., $\varepsilon_{-}, 1840-1843$ (1976).

40. Ilan, Y.A., Czapski, G. The Reaction of superoxide radical with Iron complexes and E.D.T.A. studied by pulse radiolysis. B.B.A., 498 , 386-394 (1977).

41. Ilan, Y.A., Czapski, G。 On the generation of the hydroxylation agent from superoxide radical - can the Haber Weiss reaction be the source of oH radicals? Photo Chem. \& Photo Biol., in print.

42. Ilan, Y.A., Samuni, A., Chevion, M., and Czapski, G. Quarternary states of Methemoglobin and its valence Hybrid. J. Biol. Chem., 253, 82-86 (1978).

43. Samuni, A., Chevion, M., Halpern, Y。S。, Ilan, Y.A. and Czapski, G. Radiation - induced damage in T4 Bacteriophage. Rado. Reso - in print.

44. Ilan, Y。, Ilan, Y.A. and Czapski, G. Do Copper ions influence the reduction of Ferricytochrome $C$ by $0_{2}^{-}$? B.B.A., 503, 0000 (1978). 


\section{GRADUAIEE STUDENTS TRAINED :}

1。B. Halperin

2. A. Samuni

3. R. Yelin

4. I. Duchovni

5. A. Samuni

6. D. Behar

7. E. Peled

8. D. Meisel

9. A. Gaaton

10. Y。A. I Ian

11. Y。Ilan

12. M. Pick
- received his M.Sco degree

11

11

11

11

II

11

11

11

- received his $\mathrm{Ph} . \mathrm{D}$. degree

- " " " "

- " " " "

$\begin{array}{llllllllll} & 11 & 11\end{array}$

$\begin{array}{lllll} & 11\end{array}$

" " "

- will receive his $\mathrm{Ph} . \mathrm{D}$ 。 degree

- started Ph.D。 in 1974 


\section{ACHIEVEMENTS OF RESEARCH PROJECT DURING THE LAST YEAR}

The project was continued along some of the lines proposed last year.

During this year, Progress Report Nos.49-54 were submitted.

Three publications appeared and four further publications have been submitted to Journals, of them three are in print.

The work carried out during the last two years dealt with the following problems:

\section{A. "EXPERIMENTAL RESULTS}

1) THE "HABER.WEISS" REACTION AS AN EXPLANATION OF THE TOXIDITY OF $\mathrm{O}_{2}^{-}$

In many biological systems, the role of $\mathrm{O}_{2}^{-}$in hydroxylation and toxic processes, was assumed to be due to the formation of $\mathrm{OH}^{\circ}$ radicals. The Haber Weiss reaction (1) $-\mathrm{H}_{2} \mathrm{O}_{2}+\mathrm{O}_{2}^{-} \rightarrow \mathrm{OH}^{\circ}+\mathrm{O}_{2}$ - was suggested as the origin of this activity. In this study it is shown that this reaction pathway is too slow, and that probably $\mathrm{OH}^{\circ}$ is formed from the reaction of complexes superoxide with $\mathrm{H}_{2} \mathrm{O}_{2}$ or/and from the reduction of $\mathrm{Fe}$ (III), bound to biological compounds, by $\mathrm{O}_{2}^{-}$, the reduced $\mathrm{Fe}$ (II) can then react with $\mathrm{H}_{2} \mathrm{O}_{2}$ as a Fenton reagent, to yield $\mathrm{OH}^{\circ}$ 。 It is also shown that singlet oxygen cannot be formed in these biological systems neither from the dismutation of $\mathrm{O}_{2}^{-}$nor from the reaction of $\mathrm{O}_{2}^{-}$with $\mathrm{OH}^{\circ}$. Singlet oxygen may be formed from the reduction of metal complexes by $0_{2}^{-}$。

2) ONE ELECTRON REDUCTION OF METMYOGLOBIN \& METHEMOGLOBIN AND THE REACTTON OF THE REDUCED MOLECULE WITH $\mathrm{O}_{2}$

We have used the pulse radiolysis technique to reduce with solvated electrons $\left(\mathrm{e}_{\mathrm{aq}}^{-}\right)$a single $\mathrm{Fe}$ (III) site im methemoglobin and metymoglobin. The reduction process was followed spectrophotometrically and the reactions rate constants were measured: $k_{e_{a q}}+$ methemoglobin $=6.5^{+}-1 \times 10^{10} M^{-1} \mathrm{sec}^{-1}$. $\mathrm{k}_{\mathrm{eq}}^{-}+$metymoglobin $=2.5^{+}-.3 \times 10^{10} \mathrm{M}^{-1} \mathrm{sec}^{-1}$. Approximately $60 \%$ of the $\mathrm{e}_{\mathrm{aq}}^{-}$ have probably reacted with the globin moiety. 
We followed the reaction of the reduced proteins to yield the oxyderivatives and measured the rate constants of the oxygenation processes $k_{\text {reduced }}$ methemoglobin $+0_{2}=2.6 \pm 0.6 \times 10^{7} \mathrm{M}^{-1} \mathrm{sec}^{-1}$ and $\mathrm{k}_{\text {myglobin }}+0_{2}=1.8 \pm 0.2 \times 10^{7}$ $\mathrm{M}^{-1} \mathrm{sec}^{-1}$. A11 the rate constants were measured at $\mathrm{pH}=6.8, \mathrm{~T}=22^{\circ} \pm 2^{\circ} \mathrm{C}$ 。

The high rate constant for reduced methemoglobin indicates that one-site reduced methemoglobin is probably in the $\mathrm{R}$ state, as predicted for methemoglobin from $x$-ray analysis.

The spectra of the reduced and oxygenated.species were measured under similar conditions at $\lambda=450-650 \mathrm{~nm}$. We were able to follow slight changes in the microsecond time scale, these changes were attributed to conformational changes.

We were not able to detect any reaction between the radical $\mathrm{O}_{2}^{-}$and the hemin group (which would result in a complex such as heme $-0_{2}$ ). This may be due to kinetic reasons.

3) THE OXIDATION OF $\alpha$ AND $\beta$ CHAINS BY FERRICYANIDE IN A ONE SITE REDUCED METHEMOGLOBIN .

We were able to give the first direct evidence that $\alpha$ and $\beta$ chains in hemoglobin have different reactivities. This was demonstrated in the reaction with ferricyanide. The difference in reactivities was by a factor of two.

We are extending this study to other reactants.

4) THE EFFECT OF COPPER IONS ON THE REDUCTION OF CIII BY $\mathrm{O}_{2}^{-}$

Recently, it was suggested that the measured rate of reduction of ferricytochrome $c$ by $\mathrm{O}_{2}^{-}$below $\mathrm{pH}=8$, was too high in the presence of high concentrations of formate.

The high values were attributed to the presence of impurities of copper, which compete on $0_{2}^{-}$. This assumption is consistent with either a decrease in the reduction yield of CIII in the presence of copper, or with a very fast reaction of $\mathrm{Cu}(\mathrm{I})$ with $\mathrm{CIII}$ 。

It was previously shown by us and by others that the reduction yield of CIII by $\mathrm{O}_{2}^{-}$is $100 \%$. We measured the rate of reduction of CIII by $\mathrm{Cu}$ (I) and found that this reaction is slow: $k=(1.5 \pm 0.5) \times 10^{3} \mathrm{M}^{-1} \mathrm{~s}^{-1}$. 
Therefore, our results rule out the possibility that below $\mathrm{pH}=8$ copper impurities affect the the measured rate constant of the reduction of CIII by $\mathrm{O}_{2}^{-}$

The rate of reduction of $\mathrm{Cu}(\mathrm{II})$ by $\mathrm{CO}_{2}^{-}$was also determined $k=(1.5 \pm 0.3) \times 10^{8} \mathrm{M}^{-1} \mathrm{~s}^{-1}$.

Radiation damage to bacteriophage T4 and E. Coli

Oxygen is well. known to enhance the radiation damage of cells. (O.E.R. oxygen enhancement ratio). This effect is generally attributed to damage to the DNA.

We have chosen to study this problem first with Bacteriophage T4, and will than extend it to $\mathrm{E}$. Coli.

In this study we wanted to elucidate the following problems:

a) Is the radiation damage an endogenous, or exogenous effect.

b) Is the damage direct or indirect effect.

c) Which radicals are mainly respobsible for the radiation damage.

d) What is the role of oxygen in enhancing damage.

e) What is the radiosensitizing mechanism of-oxygen and other radiosensitizers.

5) DETERMINATION OF THE RELATIVE ROLE OF EXOGENOUS AND ENDOGENOUS EFFECTS

We developed a technique to determine the relative contributions of the endogenous $\&$ exogenous effects. By irradiating the organisms in the presence of Polyethylene glycol, with molecular weight of 4000 in the presence of $\mathrm{N}_{2} \mathrm{O}$ we are scavenging all the radicals formed in the solution. On the other hand this high molecular weight scavenger does not penetrate into the organism. and therefore does not effect any endogenous damage. Using this technique, we have shown that with Bacteriophage $\mathrm{T} 4$ almost all the radiation damage is by an exogenous effect. Preliminary results show that with E. Coli the majority of the effect is endogenous. 
6) THE IDENTIFICATION OF THE SPECIES CAUSING THE RADIATION DAMAGE

AND THE RELATIVE ROLE OF DTRECT AND INDIRECT RADIATION DAMAGE

The radiation forms mainly $\mathrm{OH}^{\circ}$ radicals and solvated electrons. In the presence of oxygen $\mathrm{O}_{2}^{-}$is formed from $\mathrm{e}_{\mathrm{aq}}^{-}$.

In order to determine the toxidity of these radicals we carried out the following irradiations:

a) Solutions with formate and oxygen. In this system only $\mathrm{O}_{2}^{-}$is present, as both $\mathrm{OH}^{\circ}$ and $\mathrm{e}_{\mathrm{aq}}^{-}$are converted into $\mathrm{O}_{2}^{-}$.

b) $\mathrm{N}_{2} \mathrm{O}$ saturated solutions. In this case all radicals are converted to $\mathrm{OH}^{\circ}$.

c) Helium saturated solutions. Here wé get roughly equimoler concentrations of $\mathrm{OH}^{*}$ and $\mathrm{e}^{-}$aq

d) Oxygen saturated solutions. Here we get roughly equal amounts of $\mathrm{OH}^{\circ}$ and $\mathrm{O}_{2}^{-}$

e) $\mathrm{N}_{2} \mathrm{O}$ saturated solution with some 0xygen. Here all radicals are converted to $\mathrm{OH}$ but $\mathrm{O}_{2}$ is present!

Using these systems we were able to show that with bacteriophage T4 practically al the damage is due to $\mathrm{OH}^{\circ}$. Neither $\mathrm{O}_{2}^{-}$nor $\mathrm{e}_{\text {aq }}^{-}$does damage the phage. The apparent damage caused by $\mathrm{O}_{2}^{-}$can be implicated due to the enhancement formed by $\mathrm{O}_{2}$. The lack of any damage when only $\mathrm{O}_{2}^{-}$are formed (case a) rules this out. In the next paragraph this point will be extended.

\section{7) THE EFFECT OF OXYGEN OER}

The fact the $\mathrm{O}_{2}$ roughly doubles the radiation damage seemed to indicate that $\mathrm{OH}$ and $\mathrm{O}_{2}^{-}$are toxic while $\mathrm{e}_{\mathrm{aq}}^{-}$does not do any damage. The fact that in . $\mathrm{N}_{2} \mathrm{O}$ saturated solutions the radiation damage is similar to that in $\mathrm{O}_{2}$ saturated systems seemed to support this hypothesis.

We found that adding some $\mathrm{O}_{2}$ to $\mathrm{N}_{2} \mathrm{O}$ does double the damage caused in $\mathrm{N}_{2} \mathrm{O}$ or $\mathrm{O}_{2}$ saturated systems. This indicates that the radiation damage is only due to $\mathrm{OH}^{\circ}$. The role of $\mathrm{O}_{2}$ is to increase the radiation damage caused by $\mathrm{OH}^{\circ}$. 
Apparent1y $\mathrm{OH}+\mathrm{RH}$ yield $\mathrm{R}$ which reacts with 0 to form $\mathrm{RO}_{2}$. This last reaction fixates and enhances the damage.

THE REACTION OF $\mathrm{O}_{2}^{-}$and $\mathrm{CO}_{2}^{-}$WITH IRON COMPLEXES OF EDTA

The reactions of $\mathrm{Fe}^{3+}$-EDTA and $\mathrm{Fe}^{2+}$-EDTA with $\mathrm{O}_{2}^{-}$and $\mathrm{CO}_{2}^{-}$were investigated in the $\mathrm{pH}$ range $3.8-11.8$. Around neutral $\mathrm{pH} \mathrm{O}_{2}^{-}$reduces $\mathrm{Fe}^{3+}$-EDTA with a rate constant which is $\mathrm{pH}$ dependent. At higher $\mathrm{pH}$ values this reaction becomes much slower. The $\mathrm{CO}_{2}^{-}$radical reduces $\mathrm{Fe}^{3+}$-EDTA independent of $\mathrm{pH}$. At $\mathrm{pH} 9-11.8$, $\mathrm{Fe}^{2+}$-EDTA forms a complex with $\mathrm{O}_{2}^{-}$with $\mathrm{k}_{\mathrm{Fe}} \mathrm{e}^{2+-\mathrm{EDTA}}+\mathrm{O}_{2}^{-}=2 \cdot 10^{6}-4^{\circ} 10^{6} \mathrm{M}^{-1} \cdot \mathrm{s}^{-1}$ which is $\mathrm{pH}$ dependent. We measured the spectrum of $\mathrm{Fe}^{2+}-\mathrm{EDTA}^{2} \mathrm{O}_{2}^{-}$and calculated $\mathrm{E}_{\max }^{290} \mp 6400 \pm 800 \mathrm{M}^{-1} \cdot \mathrm{cm}^{-1}$ in air-saturated solutions. In $0_{2}$-saturated solutions another species is formed with a rate constant of $7 \pm 2 s^{-1}$. This intermediate absorbs around $300 \mathrm{~nm}$ but we were not able to identify it.

\section{B. DEVELOPMENT OF EXPERIMENTAL METHODS}

1) COUPLING THE PULSE RADIOLYSIS TO A COMPUTER

The advantage of coupling the computer to the pulse set up is obvious, and this is done recently in different laboratories. We are doing the same thing in a somewhat different way.

In addition, to using the computer to control the whole experimental set up, (syncronization of the pulse, the light pulse, pulse length, delays etc.) we developed the following principles for data storage. For relatively slow signals, when every $5 \times 10^{-6} \mathrm{sec}$ a point is recorded, the output of the photomültiplier is fed through and A- to D converter into a NOVA computer. For fast signals we developed the following method. The P.M. signal is displaced on an osciloscope screen which serves as a temporary memory and is capable to display very fast pulses, depending on the osciloscope speed (1ess then $10^{-8} \mathrm{sec} / \mathrm{cm}$ ). The trace on the screen is taken by a T.V. camera which output is fed into the computer. The data analysis thereafter are treated by the computer. The computer prograns ârétalready working and the use of the A to $D$ converter for slow events does operate. In addition we purchased a Biomation which will enable us to record fast processes: We still continue to develop the fast $T$. $V$. camera technique. We hope to finish this development within the next six to nine months. 


\section{NEW OBJECTIVES OF CONTINUATION OF THE PROJECI}

Part of the objectives as proposed previously were accomplished, as described earlier, while other objectives will be further studied. Our main effort during the previous year was dedicated to the problem of the determination of redox potentials of free radicals with special priority to the redox potential of $0_{2}^{-i}$

During the last year our main interest and emphsis was given to the role of $\mathrm{O}_{2}^{-}$in biological systems. This mainly in studying the possibility of formation of $\mathrm{OH}^{\circ}$ from $\mathrm{O}_{2}^{-}$, and the role of $\mathrm{OH}^{\circ}, \mathrm{O}_{2}^{-}$and oxygen in radiation damage to cells, and the mechanism of oxygen toxidity in biological processes.

From the progress of our studies throughout this last year, we intend to give priority in the future to the following problems, most of them proposed last year. The proposal of objectives outlined here are for the next 2-3 years of our research.

\section{ROLE OF $\mathrm{O}_{2}$ AND OF $\mathrm{O}_{2}^{-}$IN RADIODAMAGE}

The contributions of molecular oxygen and of various water-radicals to the biological radiodamage in $\mathrm{T} 4$ bacteriophage were studied. We will extend these studies to E. Coli $B$, and various mutants of E. Coli. The test organisms are $\gamma$-irradiated in buffered suspensions and the spectrum of the water-radicals is controlled by a careful choice of the saturating gases and the radical-scavengers added. Thus, it is possible to distinguish between the contributions of the various radicals as well as between the effects of $\mathrm{O}_{2}$ and $\mathrm{O}_{2}^{-}$.

The use of radical scavengers which do not penetrate the cell will enable a better distinction between the endogenous and exogenous effects involved. The results showed that for a $\mathrm{T} 4$ bacteriophage the biological damage is predominantly caused by $\mathrm{OH}^{\circ}$ while $\mathrm{e}_{\mathrm{aq}}^{-}$as well as $\mathrm{O}_{2}^{-}$do not contribute to the radiodamage. The results also indicated that the oxygen enhancement in the systems studied cannot be atributed to the formation of $\mathrm{O}_{2}^{-}$from $\mathrm{e}_{\text {aq }}^{-}$and $\mathrm{O}_{2}$, but rather to the direct interaction of $\mathrm{O}_{2}$ with the target bio mulecules.

Another conclusion which is supported by our results is that in T4 bacteriophage the radiation effect is predominantly indirect. 
We plan the following studies in this direction:

1) To extend our preliminary studies with E. Coli. B. and further establish the identity of the radicals responsible for the radio damage and the role of $\mathrm{O}_{2}$. This in addition to determine the contribution of direct effect and the relative role of endogenous damage.

2) Comparison of the radiosensitivity of E. Coli mutants (C600 and HB101 for example) one of which cannot repair its damaged DNA. This study can help to distinguish between the oxygen effects on the bacterial DNA as compared to other cellular component.

3) Comparison of the above two mutants as hosts for irradiated T4.viruses. The results of such a study may shed more light on the role of oxygen and the water radicals in the inactivation of the viral DNA.

4) The effect of radiosensitizers ("electron affinic", "firee radicals") as mimic compounds for the oxygen effect.

It is aimed to extend the previous study further and check the effect and sensitization mechanism of the radiosensitizers on the biological systems préviously studied.

II. THE SPECIFITY OF SUPEROXIDE DISMUTASE

The wide scale occurance of SOD in practically all the cells, is well established. One clear role of SOD is to catalyze the dismutation of $\mathrm{O}_{2}^{-}$.

Many questions on the toxidity of oxygen and the protective role of SOD could be clarified if we would be sure that SOD does only react on $\mathrm{O}_{2}^{-}$and not on biological peroxides or hydroperoxides.

We plan to study if SOD does react with peroxides and hydroperoxides. The substrates planed to be studied are $\mathrm{RO}_{2}^{\circ}$, where $\mathrm{R}$ are alcohol radicals and other biological peroxides, such as those formed from DNA, Lipids and Linoleic acids.

III. REDUCTION MÉCHANISM OF CYTOCHROME C, by $0_{2}^{-}$ANT OTHER REDUCTANTS

In order to understand better the reduction mechanism of cytochrome $C$ by $0_{2}^{-}$, we will study these reaction with derivatives of Cytochrome $\mathrm{C}$. We will 
also study the reduction of these derivates with $\mathrm{e}_{a \mathrm{aq}}^{-}, \mathrm{CO}_{2}^{-}$and $\mathrm{CH}_{3} \mathrm{CH}^{\circ} \mathrm{OH}$.

The derivatives which we will use are Cytochrome $C$ with the following modifications: a) Cyt $\mathrm{C}$ where all the lysines are acetylated. This modification changes mainly the charge and not the conformation. b) Cyt. C wherev : all lysines are succinilated - this changes, both the charge and opens the conformation. c) Cyt. C where the methionines are carboxymethylated - this opens the conformation but does not alter the charge.

The results of these studies will enable us to understand the effect of charge and conformation on the reduction mechanism.

\section{PULSE RADIOLYSIS STUDY OF THE BINDING OF $\mathrm{O}_{2}$ TO REDUCED METHEMOGLOBIN A}

Using the pulse radiolysis, valence hybrids may be formed from methemoglobin. These valence hybrids are characterized by that they contain a single-reduced heme in the tetramer. We intend to study the reaction of molecular oxygen with the valence hybrid in the absence and presence of organic phosphates as a function of $\mathrm{pH}$. The results will shed light on the relation between the affimity state of the valence hybrid and the quaternary structure of methemoglobin $A$.

\section{PULSE RADIOLYSIS STUDY OF FETAL HUMAN METHEMOGLOBIN}

Fetal hemoglobin that is stripped of organic phosphates shows a reduced affinity' towards ogygen when compared to stripped aduld hemoglobin (hemoglobin A). In the presence of organic phosphates, like inositol hexaphosphate or 2,3-diphosphoglycerate, the situation is reversed. This explains the mechanism for oxygen supply to the fetus from his mother.

We intend to study the reaction of molecular oxygen with valence hybrids that will be formed radiolytically from human fetal methemoglobin. The reaction will be studied in the presence and absence of organic phosphate as a function of $\mathrm{pH}$.

VI . THE REACTION $0_{2}^{-}$WITH THEMOGLOBIN \& METHEMOGLOBIN

$\mathrm{O}_{2}^{-}$is known to react both as a reducing agent $\left(\mathbf{i}_{\circ} \mathbf{e}_{0}, \mathrm{cyt} \underline{c}(\mathrm{III})+\mathrm{O}_{2}^{-}-\mathrm{O}_{2} \cdot \mathrm{O}_{-3}\right.$ cyt. $c(I I))$ and as an oxidizing species $\left(i_{\circ}, e_{\circ} \mathrm{Fe}(\mathrm{CN})_{6}{ }^{-4}+\mathrm{O}_{2}^{-} \longrightarrow \mathrm{Fe}(\mathrm{CN})_{6}+{ }^{-3} \mathrm{O}_{2}\right.$ ) By analogy, $\mathrm{O}_{2}^{-}$could, in principle, either reduce oxyhemoglobin(IV) to 
methemoglobin(III), or in turn, it could oxiu_e the heme-iron(II) in deoxyhemoglobin to methemoglobin.

We intend to study the mechanism of and the effect of the allosteric modifier, IHP, on the reaction between hemoglobin and superoxide radical.

VIT. PULSE RADYOLYSIS STUDY OF RADICALS WITH ISOURAMIL

AND RELATED PYRIMIDINES

Favism is the acute hemolytic crisis following the ingestion of broad beans (Vicia faba) in glucose-6-phosphate dehydrogenase deficient individuals.

Isovramil (2,4,5 trihydroxy pyrimidine) and divicine 2,6 diamino - 4,5 dihydroxy pyrimidine), two substances found in the bean, are implicated as the toxic constituents. In addition to their role in the etiology of Favism, these two compounds are pyrimidines of similar sturcture to those pyrimidines found in DNA, i。e, Cytozine and Thymine.

We intend to study the reactions of these pyrimidines and their derivatives with $\mathrm{e}_{\mathrm{aq}}^{-}, \mathrm{OH}^{\circ}$ and $\mathrm{O}_{2}^{-}$.

VII. PRODUCTION OF STABLE SOLUTIONS OF $0_{2}^{-}$AND STUDIES OF REACTIONS OF $\mathrm{O}_{2}^{-}$

We will construct a system based on milipore-CO Cartrige to purify alkaline solutions. It is well known that in the purified solutions the life time of the $\mathrm{O}_{2}^{-}$is $\mathrm{pH}$ dependent, and at high $\mathrm{pH}^{\prime} \mathrm{s}$ it can exist for a few hours.

We intend to use a flow system and mix these alkaline solutions of $0_{2}^{-}$ with various solutes in buffered solutions, and thus will be able to study the reactions of $\mathrm{O}_{2}^{-}$round neutral $\mathrm{pH}$. In our flow system we will use both optical and ESR detection.

\section{a) Catalyst for the Haber Weiss reaction}

We intend to study the effect of various metal complexes as catalysts on the Haber Weiss reactions:

$$
\mathrm{O}_{2}^{-}+\mathrm{H}_{2} \mathrm{O}_{2} \stackrel{\text { catalyst }}{\longrightarrow} \mathrm{OH}+\mathrm{OH}^{-}+\mathrm{O}_{2}
$$

b) Oxidation Reduction Potentials of $\mathrm{HO}_{2}$ and $\mathrm{MHO}_{2}$ Complexes

In order to understand further the reactions of $\mathrm{HO}_{2}$, and complexes of $\mathrm{HO}_{2}$ with cations or with metal porphyrins, it will be very useful to determine their oxidation reduction potentials in the reactions 


$$
\begin{aligned}
& \mathrm{M}+\mathrm{O}_{2}+\mathrm{X}^{-} \rightleftharpoons \mathrm{MHO}_{2}+\mathrm{X} \rightleftharpoons \mathrm{MHO}-\mathrm{MH}_{2}^{-}+\mathrm{X}^{+} \\
& \mathrm{O}_{2}+\mathrm{H}^{+}+\mathrm{X}^{-} \rightleftharpoons \mathrm{HO}_{2}+\mathrm{X} \rightleftharpoons \mathrm{HO}_{2}^{-}+\mathrm{X}^{+}
\end{aligned}
$$

This will be done in a similar way done by Hayon et al and by us, by chosing reagents $X$ with suitable oxidation reduction potentials.

c) Recation Rates of $\mathrm{HO}_{2}$ and $\mathrm{O}_{2}^{-}$with Various Solutes

We will study the rate of $\mathrm{HO}_{2}$ radical with various solutes. These reactions may occur in biological processes and it would be interesting to study these rates. Furthermore, $\mathrm{HO}_{2}$ and $\mathrm{O}_{2}^{-}$may react both as reducing and oxidizing agents.

$$
\begin{aligned}
& \mathrm{HO}_{2}+\mathrm{x} \longrightarrow \mathrm{HO}_{2}^{-}+\mathrm{x}^{+} \\
& \mathrm{HO}_{2}+\mathrm{x} \longrightarrow \mathrm{O}_{2}+\mathrm{x}^{-}
\end{aligned}
$$

We intend to study these reactions with cytochrome $\mathrm{C}$ and other metal porphyrins.

d) Oxidation Mechanisms With $\mathrm{O}_{2}$

We intend to study the oxidation mechanism of simple Ions such as $\mathrm{Cr}^{2+}$ or $\mathrm{V}^{2+}$ with $\mathrm{O}_{2}$. These reactions may be one electron transfer reaction in which case $\mathrm{O}_{2}^{-}$would be formed. This study may be extended to oxidations of the reduced metal porphyrins by $\mathrm{O}_{2}$, such as Ferrocytochromes at appropriated $\mathrm{pH}$.

e) Properties of $\mathrm{MHO}_{2}$ Complexes

We have shown that many cations $\mathrm{M}\left(\mathrm{M}=\mathrm{Ce}^{+3}, \mathrm{Ti}^{+4}, \mathrm{U}^{+6}, \mathrm{Th}^{+4}, \mathrm{Zr}^{+4}, \mathrm{Nb}^{+4}, \mathrm{La}^{+3}\right.$, $\mathrm{V}^{+5}, \mathrm{Hf}^{+4}$, etc.), form coplexes with $\mathrm{HO}_{2}$. We intend to find out if $\mathrm{O}_{2}^{-}$also forms such complexes.

Moreover, we will study some of the main properties of these complexes, also with metal porphyrins such as:

1) Their ESR spectra and optical spectra;

2) The rate of their formation in the reaction $\mathrm{HO}_{2}$ or $\mathrm{O}_{2}^{-}+\mathrm{M} \longrightarrow \mathrm{MHO}_{2}$;

3) The $\mathrm{pK}$ of the equilibrium $\mathrm{M}+\mathrm{HO}_{2} \Longleftrightarrow \mathrm{MHO}_{2}$;

4) The decay kinetics of $\mathrm{MHO}_{2}$;

5) Reactivities of $\mathrm{MHO}_{2}$ with other solutes such as cations as well as organic solutes, both as reducing and as oxidizing agents. 
These properties are interesting as such, as well as necessary in order to understand the exchange mechanism of

$$
\mathrm{MHO}_{2}+\mathrm{M}^{\prime} \underset{\mathrm{M}}{\longrightarrow}+\mathrm{M}^{\prime} \mathrm{HO}_{2}
$$

These studies will be carried out using flow system with ESR detection, as well as by using pulse radiolysis with optical detection.

\section{f) Possible Implications to Biological Systems}

We will try to extend the work of $\mathrm{M}-\mathrm{HO}_{2}$ complexes, their exchange reactions, etc:, where $M$ and $M^{\prime}$ ' are not bare cations but substances of biological interest, such as cytochromes, for instance. 


\section{SIGNIFICANCE OF THIS RESEARCH PROJECI}

This research project concerns the chemical and physical properties of the peroxy radicals. Three radicals, $\mathrm{OH}, \mathrm{e}_{\mathrm{aq}}$ and $\mathrm{H}$, are formed in the radiolysis of water but in oxygenated solutions the principal radicals are $\mathrm{OH}$ and $0_{2}^{-}$. The same radicals are formed in the photolysis of certain aqueous solutions in many chemical reactions. Any understanding of the radiation chemistry and photochemistry of such systems is impossible without the knowledge of the properties of these radicals that we are attempting to gain.

These oxygen radicals are also of great importance in radiation biology and photobiology. The toxidity of $\mathrm{O}_{2}^{-}$and its role in biological processes is of major interest.

Therefore, the study of the properties of $\mathrm{O}_{2}^{-}$and $\mathrm{OH}$ is of major importance in understanding the biological function of $\mathrm{O}_{2}^{-}$.

The main significance of this project is in the following senses:

1) The extension of generation of $\mathrm{HO}_{2}$ or $\mathrm{O}_{2}^{-}$by chemical reactions to study properties of $\mathrm{O}_{2}^{-}$at neutral $\mathrm{pH}$ which is of greater interest from the biological point of view.

2) The study of complexes of $\mathrm{HO}_{2}$ with metal ions and such exchange reactions of $\mathrm{HO}_{2}$ between several metal ion complexes is of great interest.

The ease with which the $\mathrm{HO}_{2}$ radical complexes with metal ions is somewhat surprising. The significance of this point to radiation biology and other biological chemical processes in unknown but it would seem that further investigation of these complexes is desirabie. The comparison of our studies in the properties of $\mathrm{MHO}_{2}$ complexes with the enzymatic catalysis of $\mathrm{HO}_{2}$.

This effort may lead to have biological interest as such a reaction may play a role in physiological processes as $\mathrm{H}_{2} \mathrm{O}_{2}$ decomposition, biosynthesis or ther biological oxidation reduction reactions.

3) To understand further the oxidation reduction reactions of $\mathrm{HO}_{2}$ or its complexes both in biological and nonbiological systems, the thermodynamical information of these species is crucial.

We intend to determine not only $\mathrm{pK}$ values of $\mathrm{HO}_{2}$ in its complexes, but also $E^{\circ}$ - the redox potential of both $\mathrm{HO}_{2}$ and its complexes. 
In order to demonstrate the importance and the use of these data for biological problems, we will bring two examples:

In studies of the enzymatic mechanism of the action of superoxide dismutase it was argued in the literature whether a complex between the enzyme and $\mathrm{O}_{2}^{-}$ is first formed. We were able to show that such a complex is most probably not formed - this was possible due to the knowledge of the redox potentials of the enzyme and that of the $\mathrm{O}_{2}^{-}$.

Another example is the question if in the reaction of $\mathrm{O}_{2}$ with cytochrome oxdidase $\mathrm{O}_{2}^{-}$may be formed? It was argued against this possibility on grounds of thermodynamical arguments, with our value of $\mathrm{E}^{\mathrm{O}}$ of the $\mathrm{O}_{2}^{-}$we were able to show that one cannot rule out the possible existence of $\mathrm{O}_{2}^{-}$in this system. The last example demonstrates the application of such data for analyzing the possible mechanism of some enzymatic reactions on grounds of the thermodynamical data.

4) The toxidity of $\mathrm{O}_{2}^{-}$and its role in biological systems is quite obscure. This study is aimed to understand how $\mathrm{O}_{2}^{-}$functions in biological system. We have shown that $\mathrm{O}_{2}^{-}$does not react through the "Haber Weiss" reaction, and we search for alternative mechanisms. This study has also implication on the formation and function of singlet oxygen, and the mechanism of its toxidity. 5) In our studies with hemoglobins, we may get better understanding on the spicifity of the various conformations in chemical reactions such as $0_{2}$ binding as well as other redox-oxidation reactions.

6) The effect of $\mathrm{O}_{2}$ as radiosensitzer is well established. Our studies may enable to determine the answer to the following questions:

a) What are the radicals responsible for radiodamage?

b) Does $\mathrm{O}_{2}^{-}$cause any radiation damage?

c) What is the mechanism of $\mathrm{O}_{2}$ on the sensitization process.

d) How do radiosensitizers react.

7) We will try to establish if SOD is specific and reacts with $0_{2}^{-}$only or also with other organic biological peroxides and Hydroperoxides. This is an important question as to the role of SOD in the cell. 


\section{SCIENTIFIC PERSONNEL}

Prof. G. Czapski will be responsible for the project and will spend all his time in research on it.

Mrs。 Yael Ilan (Ph.D) will continue to work with fast reaction flow system on reactions $\mathrm{HO}_{2}$ and $\mathrm{O}_{2}^{-}$using both optical and ESR detection. $\mathrm{Mr}$. and Mrs. Ilan will extend this study also on complexes of $\mathrm{HO}_{2}$ with metal ions and metal porphyrins, mainly on various derivatives of Cytochrome C. They will also study, the formation of $\mathrm{O}_{2}^{-}$and $\mathrm{OH}^{\circ}$ in biological systems. $\mathrm{Mr}$. E. Brener will finish the coupling of the accelerator and pulse radiolysis technique to our new NOVA computer: also for fast events.

Dr.A. Samuni, senior lecturer in the department of Microbiology, will work on the role of $\mathrm{O}_{2}^{-}$in radiation damage of cells. He will study the role of $\mathrm{O}_{2}$ in the oxygen enhancement ratio (OER) as well as the mechanism of various radiosensitizers and protectors.

The Department of Physical Chemistry of the Hebrew University will contribute towards the Project, both in personal and other expenses, considerably in excess of the funds requested under this contract. (For example, in 1967-1978 about \$400,000 was spent for the linear accelerator and experimental equipment, in addition to another $\$ 100,000$ for construction of the accelerator building, and lately additional $\$ 150,000$ were spent for computer being coupled to the pulse equipment and to the accelerator).

\section{QUALIFICATIONS OF PRINCIPAL INVESTIGATOR}

Professor G. Czapski, the Principal Investigator, studied at the Hebrew University, where he received his M.Sc。 and Ph.D degrees in Physical Chemistry。 From 1960 to 1962 he was research associate at Brookhaven National Laboratory, N.Y., U.S.A., working on radiation chemistry of aqueous solutions with Drs. A.O. Allen and H.A. Schwarz. During the summer of 1962 he was invited for approximately a month as guest of the Radiation Chemistry Department at the "Boris Kidrich Institute", Vinca, Yugoslavia. In the summer of 1963 he spent five months as resident research associate at Argonne National Laboratory, Illinois, U.S.A., working with Dr. L.M. Dorfman on pulse radiolysis. In 1964 he was guest scientist at the Nuclear Research Center Democritus in Athens, 
Greece, and in the summer of 1965 stayed as guest scientist at Brookhaven National Laboratory. At the present, Professor Czapski is the Director of the Linear Accelerator Laboratory. In 1970 he was guest Professor at Carnegie Mellon University. Since 1964 Professor Czapski is also guest professor at Te1-Aviv University. For the years 1975-1978 he was elected as Rector of the Hebrew University.

Professor Czapski's interest was centered in the properties and identity of radicals produced by radiation in aqueous systems. The study of reactions of hydrogen atoms was carried out by producing them in the gas phase by an electrodeless discharge and introducing them into aqueous solutions. The different oxidation mechanisms were investigated, and evidence for $\mathrm{H}_{2}^{+}$and hydride intermediate was given in several systems which were studied. By using the kinetic salt effect, it was first proven that one form of the reducing radical has a unity negative charge - thus being solvated electron - an assumption which was previously postulated. In other studies, using fast flow system techniques coupled with high intensity radiation, he found that formation of $\mathrm{HO}_{2}, \mathrm{O}_{2}^{\infty}$ radicals and of $\mathrm{H}_{2} \mathrm{O}_{3}$.

The formation of $\mathrm{HO}_{2}$ radical was studied with fast kinetic techniques in the reaction of $\mathrm{Ce}^{+4}$ and $\mathrm{H}_{2} \mathrm{O}_{2}$.

In flash radiolysis of aqueous solution, he studied the decay and formation rates and the spectra and $\mathrm{pK}$ of the $\mathrm{HO}_{2}$ radicals. In addition new intermediates in alkaline solutions were found, one of which probably is the ozonide ion $\left(0_{3}^{-}\right)$.

The formation of complexes of $\mathrm{HO}_{2}$ with metal cations $M$ were established $\left(\mathrm{M}-\mathrm{HO}_{2}\right)$. The properties and possibly role of such complexes were studied.

Lately he was involved in the determination of redox potentials of free radicals and determined the redox potential of the $\mathrm{O}_{2} / \mathrm{O}_{2}^{-}$couple as well as that of several seniquinones.

In the last years the research of the properties of $\mathrm{O}_{2}^{-}$and its complexes was extended to biological problems.

The studied reactions of $\mathrm{O}_{2}^{-}$with cytochrome $\mathrm{C}$ and some derivatives, reactions of $\mathrm{O}_{2}^{-}$and of $\mathrm{O}_{2}$ with Hemoglobin, Methemoglobin and Oxyhemoglobin,

the role of $\mathrm{O}_{2}^{-}$in biological processes and its toxidity were studied. This is recently extended to the radiation damage of bacteriophages and E.Coli. 
The role of $\mathrm{O}_{2}^{-}$in the radiation damage is being elucidated.

Professor Czapski constructed and set up a fast reaction flow system, a flash photolysis apparatus and pulse radiolysis laboratory. The last equipment is now being coupled directly to a computer.

A list of publications is attached.

OTHER FINANCIAL ASSISTANCE

The principal investigator has no other research contracts: He had for the last six months a small grant for collaboration with the radiation biology group in the GSF Neuherberg, Germany. This grant was mainly for covering mutual visits of sceintists between these laboratories. 


\section{LIST OE PUBBLICATIONS}

1. Czapski, G., Stein, G. and Vogel, $U_{0}$, The Oxidation of $\mathrm{Fe}^{2+}$ in Aqueous Solutions by $\mathrm{H}$ atoms, Buiz. Res. Counciz Israel, 7A, 231-232 (1958).

2. Czapski, G。 and Stein, G。, Oxidation of Ferrous Ion in Aqueous Solution by Atomic Hydrogen, Nature, 182, 598 (1958).

3. Czapski, Go and Stein, G., The action $\circ \mathrm{H}$ atoms on Ferro-Ferri-Cyanide System, Bull. Council Israel, 8A, 147 (1959)。

4. Czapski, Go and Stein, G., The Oxidation of Ferrous Ions in Aqueous Solution by Atomic Hydrogen, J. Phys. Chem. 63, 850-853 (1959).

5. Czapski, G., Jortner, J. and Stein, G., The Oxidation of Iodide in Aqueous Solution by Atomic Hydrogen, Jo Phys. Chem., 63, 1769-1774 (1959).

6. Czapski, G. and Stein, G., The Action of Hydrogen Atoms on Ferro-FerriCyanide System in Aqueous Solutions, $J_{0}$ Phys。Chem。, 64, 219-221 (1960).

7. Czapski, G. and Jortner, Jo and Stein, G., Mechanism of the Oxidation and Reduction of Metal Ions by Hydrogen Atoms, Nature; 186, 629-630 (1960).

8. Czapski, G. and Jortner, J., Role of Ferrous Hydride in the Oxidation of Ferrous Ion by Hydrogen Atoms, Nature, 188, 50-51 (1960).

9. Czapski, G., Jortner, Jo and Stein, G., The Role of Hydrogen Atoms in the Decomposition of Hydrogen Peroxide and in the Radiation Chemistry of Water, $J_{0}$ Phys. Chem., 65, 964-966 (1961).

10. Czapski, G., Jortner, Jo and Stein, G., The Mechanism of oxidation by H. Atoms in Aqueous Solution. I. Mass Transfer and Velocity Constants, J. Phys. Chem., 65, 956-960 (1961).

11. Czapski, G。, Jortner, Jo and Stein, G。, The Mechanism of Oxidation by $H$ Atoms in Aqueous Solution. II. Reaction Mechanisms with Different Scavengers, Jo Phys. Chem., 65, 960-964 (1961)。

12. Czapski, G., Radiolysis of Hydrogen Peroxide Solution - Proceedings of the Fourth Informal Conference on the Radiation Chemistry of Water, p/ 23-25 (March 1961).

13. Czapski, G. and Allen, A。O., The Reduction Radicals Produced in Water Radiolysis Solutions of Oxygen-Hydrogen Peroxide Ion, J. Phys. Chem., 66, 262-266 (1962)。

14. Czapski,y. G。 and Schwarz, H.A., The Nature of the Reducing in Water Radiolysis, J. Phys。Chem., 66, 471-474 (1962)。 
15. Czapski, G., Bielski, B.H.J. and Sutin, No, The Kinetics of the Oxidation Hydrogen Peroxide by Cerrium (IV), J. Phys。Chem。, 67, 201-203(1963).

16. Czapski, G., Rabani, $J_{\circ}$ and Stein, G。, The Reactivity of H Atoms with Ethanol and Formate in Aqueous Solutions, Trans. Far. Soc., 58, 2160-2167 (1962).

17. Czapski, Go and Bielski, $\mathrm{B}_{\circ} \mathrm{H}_{\circ} \mathrm{J}_{\circ}$, The Formation and Decay of $\mathrm{H}_{2} \mathrm{O}_{3}$ and $\mathrm{HO}_{2}$ in Electron Irradiated Aqueous Solutions, $J_{0}$ Phys. Chem。, 67, $2180-2184$ (1963)。

18. Czapski, G。, and Schwarz H.A., The Nature of Reducing Radical in Water Radiolysis, "Series of Selected Papers in Physics" - The Physical Society of Japan, 76-80 (1963).

19. Czapski, G., On the Formation of New Intermediates in Irradiated Alkaline Solutions, Discuss Farady Soc., 63, 316-321 (1963).

20. Czapski, G。, On the Precursors of Molecular Yields, Diss. Farady Soc,. 63, 321-322 (1963).

21. Czapski, G. and Dorfman, I.M., Transient Spectra on Rate Constants in Oxygenäted Aqueous Solutions, J. Phys. Chem。, 68, 1169-1177 (1964).

22. Czapski, G。 and Stein, G。, The Reduction of $\mathrm{AgNO}_{3}$ in Aqueous Solutions by H Atoms, Israel $J_{0}$ Chem., 2, 15-19 (1964)。

23. Czapski, G。, Frowirth, N. and Stein, G., Action of Atomic Hydrogen on Ferri-Cytochrome-C in Aqueous Solution, Nature, 207, 1191-1192 (1965).

24. Czapski, G. and Allen, A.0., Radiation Chemistry of Aqueous Solution of Silver Ion, J, Phys. Chem。, 70, 1659-1662 (1966)。

25. Czapski, G. and Katakis, D。, Light Emission from Aqueous Solutions of $\mathrm{T}_{2} \mathrm{O}, J_{0}$ Phys. Chem。, 70, 637-640 (1966)。

26. Czapski, G., Pulse Radiolysis Studies in Oxygenated Alkaline Solutions, J. Phys. Chem. 71, 1683-1688 (1967)。

27. Czapski, G., Oxygenated Species in Alkaline Solutions, Proceedings of the Fifth Conference on Radiation Chemistry of Water at Notre Dame Univ., Indiana, U.S.A.91-99 (1967)。

28. Czapski, G., and Halperin, $B_{\circ}$, On the $U_{\circ} V_{\circ}$ Spectrum of $\mathrm{O}_{2}^{-}$in Solutions, Israel J. Chem., $5,185-191$ (1967).

29. Behar, D. and Czapski, Go, Flash Photolysis of $\mathrm{H}_{2} \mathrm{O}_{2}$ I: The Reaction of $\mathrm{O}_{3}^{-}$with $\mathrm{H}_{2} \mathrm{O}_{2}$, Israel $J_{0}$ of Chem。, 6 , 43-51 (1968).

30. Czapski, G。 and Ottolenghi, M。, Scavenging Kinetics in the Photochemistry of Some Ions in Aqueous Solution, Ibid., 6, 75-83 (1968. 
31. Czapski, G., Radical Yields as a Function of $\mathrm{pH}$ and Scavenger Concentration, "Advances in Chemistry Series" No。 81, 106-130 (1968)。

32. Czapski, G., Oxygen Containing Intermediates in Photochemistry and Radiation Chemistry, "Radiation Chemistry of Aqueous Systems", 211-227 (1968) Weizmann Science Press, Jerusalem.

33. Czapski, G。 and Peled, $\mathrm{E}_{\circ}$, On the $\mathrm{pH}$ dependence of $\mathrm{G}_{\text {reducing }}$ Israel $j$. of
Chem. 6, 421-436 (1968).

34. Czapski, G. and Rabani, J., The use of $0_{0}$. Paper for an Esay Ecvaluation of Oxcilloscope Traces, Tsrael $j_{\circ}$ of Chem。, 2, 167-169 (1969).

35. Czapski, G。, Samuni, A。 and Yelin, R。, The Decay of Ozone in Alkaline Solution, Israel $J_{0}$ of Chem。, $6,969-971$ (1968).

36. Czapski, Go and Samuni, A。, The kinetics of complexed and Free HO Radical in the reaction of Ydrogen Peroxide with Cerric Ion in Perchloric Acid, Israel jo of Chem. $7,361-373$ (1969).

37. Czapski, G。, Levanon, $H_{0}$ and Samuni, A。, ESR studies of uncomplexed \& Complexed $\mathrm{HO}_{2}$ radical in the reaction $\mathrm{H}_{2} \mathrm{O}_{2}$ with $\mathrm{Ce}^{4+}$ and $\mathrm{Ti}^{3+}$ ion, Israel jo of Chem. $7,375-386$ (1969)。

38. Amichai, 0., Czapski, Go and Treinin, A., Flash photolysis of the oxybromine anions, Israel j. of Chem。, $7,351-359$ (1969).

39... Czapski, G。, Ogdan, J。 and Ottolenghi, $M_{\circ}$, On the photochemical cage effect in aqueous solutions of the Halide anions, Phys. Chem. Letters, 3, 283-385 (1969)。

40. Behar, D。 and Czapski, G。, Ozonide and Hydroperoxy rdicals in flash photolysis of $\mathrm{H}_{2} \mathrm{O}_{2}$, Israel $j$ o of Chem, 699 , 69-708 (1970)。

41. Czapski, Go and Peled, E., Studies on the molecular Hydrogen Formation $\left(\mathrm{G}_{\mathrm{H} 2}\right)$ in the Radiation Chemistry of Aqueous solutions, J. Phys. Chem., 74, 2903-2911: (1970)。

42. Behar, D。, Czapski, G。 and Dochovni, I。, $\mathrm{CO}_{3}^{-}$Radical in flash photolysis and pulse radiolysis of Aqueous Carbonate solution., J.Phys.Chem., 74, 2206-2210 (1970)

43. Behar, D。, Czapski, G., Rabani, J。, Dorfman, L。M。 and Schwarz, H.A., The acid idssociation constant and decay'kinetics of the perhydroxy 1 radicals., JoPhys。Chem., 74, 3206-3211 (1970)。

44. Fojtik, A。, Czapski, G。 and Henglein, A。, Pulse radiolytic inverstigation of the carboxyl radical in Aqueous Solution, J. Phys. Chem., 44, 3204-3208 (1970)。

45. Czapski, G. and Samuni, A。, ESR study of complex formation between $\mathrm{HO}_{2}$ radical peroxy vanadium (V) ion, Israel $j_{0}$ Chem。, $\underline{8}, 563-573$ (1970). 
46. Czapski, Go and Samuni, A., Oxidation of $\mathrm{Ce}^{3+}$ by $\mathrm{HO}_{2}$ radical and $\mathrm{Ce}^{3+}$ $\ldots \mathrm{HO}_{2}$ complex formation, Israel $J$. Chem。s $\underline{8}_{\text {, }} 551-561$ (1970)。

47. Czapski, G. and Samuni, A. Complexes of $\mathrm{HO}_{2}$ radical with transtion metal ions, Jo Phys。 Chem., 74, 4592-4594 (1970).

48. Czapski, G. and Meise1, D., The role of the reaction of $\mathrm{e}^{-}$aq with $\mathrm{Fe}^{3+}$ in the radiation chemistry of acid Aqueous Solution, Inter。 $J_{0}$ Rad. Phys。 Chem。, $\underline{3}$, 11-16 (1971)。

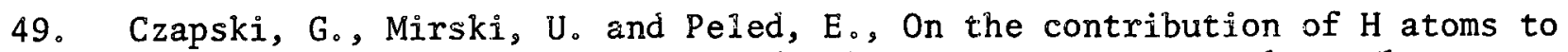
$\mathrm{G}_{\mathrm{H} 2}$ in the radiation chemistry of Aqueous Solutions, J. Phys. Chem., 75, $31-35$ (1971)。

50. Czapski, G。 and Peled, E., On the existence of dielectrons in Aqueous Solutions, Chem.Comm., 1303-1305 (1970)。

51. Czapski, G。, Radiation chemistry of oxygenated Aqueous Solutions, Ann。 Rev。Phys. Chem。, pp。171-208 (1971)。

52. Czapski, G。, Samuni, A. and Meise1, D., The Reactions of Organic Radicals Formed by Some "Fenton-Like" Reagents, J。 Phys. Chem。, 75, 3271-3280 (1971)。

53. Czapski, G., Electron Spin Resonance Studies of Short Lived Radicals Generated by Fast Flow Techniques in Aqueous Solutions, $J$ 。 Phys. Chem., 75, 2957-2967 (1971)。

54. Peled, E。 and Czapski, G., The Competition for $\mathrm{e}_{\mathrm{ag}}$ - between Several Scavengers at High Concentrations and its Implications of the Relevance of Dry Electrons in the Radiation Chemistry of Aqueous Solutions, J. Phys. Chem。, 75, 3626-3630 (1971)。

55. Samuni, A。, Meise1, D。 and Czapski, G。, The Kinetics of Oxdiation of $\mathrm{Cr}$ (II), Ti(III), and V(IV) by $\mathrm{H}_{2} \mathrm{O}_{2}$ and $\mathrm{OH}_{\circ}, J_{\circ}$ Chem。 Soc. (Dalton Trans.), 1273-1277 (1972)。

56. Peled, E., Meise1, D。 and Czapski, G., Concentration Effects of Primary Processes in the Radiation Chemistry of Aqueous Solutions, J。Phys。 Chem。, 76, 3677-82 (1972)。

57. Samuni, A。 and Czapski, G。, ESR Evidence for Nb(V) and La(III) Hydroperoxy Complexes - Report NYO-3753-22.

58. Meise1, D。, Samuni, A. and Czapski, G。, On the use of ESR - Flow Techniques in the Study of Short Living Radicals, $J$. Chem.Soc. (Perk. Sec.), 1702-1708 (1973)。

59. Czapski, G。 and Peled, E。, On the Scavening of $\mathrm{e}_{\mathrm{aq}}^{-}$and on the Possible Smoluchowski's Equation at high Concentration of Solution, J. Phys。 Chem. , 77, 893-897 (1973)。

60. Samuni, A. and Czapski, G., On the Reaction of Ce(IV) Perchlorate with $\mathrm{H}_{2} \mathrm{O}_{2}$, J. Chem. Soc。 (Dalton Trans。), 487-488 (1973)。 
61. Czapski, G。, On the Solvation Times of Electrons, editor J。 Jortner \& N.R。 Kestner "Electron in Fluids", p。127, Springer Verlag (1973).

62. Czapski, G., The Hydroperoxy Radical in Aqueous Solutions, Israel $J$. Chem. 10, $987-997$ (1972).

63. Meise1, D., Czapski, G. and Samuni, A., Hydroperoxy Radical Reactions I:ESR Study of the Complexation of $\mathrm{HO}_{2}$ with some Metal Ions, $J_{\circ} A m$. Chem。 Soc。, 95, 4148-4153 (1973)。

64. Gaathon, A., Czapski, Go and Jortner, J., Localized Excess Electrons in Dense Water Vapor, $J_{0}$ Chem。 Phys。, 58, 2648-2650 (1973)。

65. Czapski, G。, Meise1, D。 and Levanon, H., Hydroperoxyl radical reaction II-Cupric ions in modulated photolysis - EPR experiments, J. Phys. Chem., 78, 779-782 (1974)。

66. Meise1, D., Ilan, Y。A。 and Czapski, G。, Hydroperoxyl reactions III-Pulse radiolytic study of the reaction of $\mathrm{HO}_{2}$ with some metal ions., J. Phys. Chem., 78, 2330-2334 (1974)。

67. Meise1, D。, Czapski, G., Matheson, M.S. and Mulac W.A., On the existence od Dielectrons in aqueous solutions. Int. $J_{0}$ Radiat. Chem., $7,233-241$ (1974)。

68. Ilan, Y.A., Meise1, D. and Czapski, Go, The Redox Potential of the $\mathrm{O}_{2}-\mathrm{O}_{2}^{-}$ system in Aqueous Media., Israel $J_{0}$ of Chem., 12, 891-895 (1974)。

69. Meise1, D。 and Czapski, G., One Electron Transfer Equilibria and Redox Potentials of Radicals Studied by Pulse Radiolysis. $J$. Phys. Chem., 79, 1503-1509 (1975)。

70. Czapski, Go, and Peled, D. Reactions Rates of Electrons at Short Times Proceedings of the 5 th International Congress of Rad. Research P. 356366 Ed. H.I. Adler, Academic Press. Inc. N.Y. 1975.

71. Ilan, Y。A., Czapski, G. and Meise1, D. The Determination of the one electron transfer redox potential of free radicals. Proc. Israel Chem. Soc., 43rd Ann。Meeting。p.74 (1975)。

$72 \ldots$, Czapski, G。 and Peled, E。 Diffusion controlled reaction half life is shorter than 10-10 seconds., Ibid. p. 3 (1975).

73. Ilan, Y。A。, Czapski, G。, Ardon, $\mathrm{M}_{\circ}$ The Formation of $\mathrm{CrO}_{2}^{2+}$ in the reaction of $\mathrm{Cr}^{2+}$ in Aqueous Solutions. Israel J. of Chem., 13, $15-21$ (1975).

74. Ilan, Y.A., Czapski, G. and Meise1, D. The one electron transfer redox potential of free radicals。, $B_{0} B_{0} A .430,209-224$ (1976).

75. Ilan, Y.A., Rabani, J。 and Czapski, G。 One electron reduction of Memyoglobin and methemoglobin and the reaction of the reduced molecule with oxygen. Ibid。 $446,277-286$ (1976). 
76. Ilan, Y.A., Czapski, $G_{0}$ The oxidation of $\alpha$ and $\beta$ chains by ferricyanide in a one-site reduced methemoglobin., $B . B . A$. submitted.

77. Ilan, Y。A。, Czapski, G. The Reaction of superoxide radical with Iron complexes and E.D.T.A. studied by pulse radiolysis。 $B_{0} B_{0} A$. 498, 386-394 (1977)。

78. Ilan, Y.A., Czapski, G. On the generation of the hydroxylation agent from superoxide radical - can the Haber Weiss reaction be the source of $\mathrm{OH}$ radical? Photochem. and Photobiology - in print. 79. Ilan, Y。A. Czapski, G. Oxidation of heme by $\mathrm{O}_{2} / \mathrm{O}_{2}^{-}$and ferrocyanide.
$B_{\circ} B_{\circ} A_{0}$ submitted.

80. Ilan, Y。A。, Samuni, A., Chevion, M. and Czapski, G。 Quarternary states of Methemoglobin and its valence Hybrid. J. Biol. Chem., 253, 82-86 (1978)。

81. Samuni, A., Chevion, M., Halpern, Y.S., Ilan, Y.A. and Czapski, G. Radiation - induced damage in T4 Bacteriophage Radio Reso - in print.

82. Ilan, Y., Ilan, Y.A., and Czapski, G. Do Copper Ions influence the reduction of Ferricytochrome $C$ by $0_{2}^{-}$? $B_{0} B_{0} A_{\circ} \underline{503}, 0000$ (1978). 


\section{GENERAL INFORMATION}

\section{a. FACILITIES AVAILABLE}

1. Cesium $\gamma$-ray source (2000 curie).

2. Flash Photolysis appartatus. (Built in the department).

3. Several spectrophotometers.

4. Flow system for measuring fast reactions. (Built in the department).

5. An ESR Varian instrument.

6. A11 general equipment in the physical chemistry laboratory。

7. Complete pulse Radiolysis set up coupled to computer.

b. CONTRACTOR'S CONTRIBUTION TO PROJECT (no charge)

The Hebrew University constructed a flow system and flash photolysis apparatus at an approximate cost of $\$ 25,000$ for each in addition to acquiring al1 equipment mentioned above. The Hebrew University also covers $67 \%$ of $\mathrm{Dr}$. Czapski's salary (who will devote $50 \%$ of his time to this project) as well as that of part-time technicians and junior assistants.

\section{c. LINEAR ACCELERATOR LABORATORY}

A laboratory for a linear accelerator has been built, (above 3,000 sq.ft.). The budget for the accelerator with its auxiliary experimental equipment is $\$ 250,000$. The accelerator arrived in November 1968 and is operating fully with its auxiliary pulse radiolysis equipment, with detection times down to $10^{-8}$ sec.

In the last three years additional $\$ 150,000$ were invested in purchasing a Biomation, a NOVA computer, Disc, display, hard copy unit and fast printer.

These components together with the development of fast A to D converters, enable the direct control of the accelerator and pulse radiolysis set up by the computer. In addition, this set is capable of storage and evaluation of the measured data directly.

To the present time the development reached the stage that events as long as $10^{-6} \mathrm{sec}$. can be handled directly by the computer. Faster processes as short as $10^{-8} \mathrm{sec}$. will be soon handled also directly through the computer. 